\title{
DO FINANCIAL RATIOS, FIRM CHARACTERISTICS AND CORPORATE GOVERNANCE AFFECT FIRM PERFORMANCE?
}

\author{
JENNY \\ SILVY CHRISTINA \\ Trisakti School of Management \\ silvy@stietrisakti.ac.id
}

\begin{abstract}
The purpose of this research is to provide evidence about variables that influence firm performance. These variables are board size, debt ratio, firm size, firm age, return on asset, and independent board. Sample of this research are 67 manufactured companies listed in Indonesia Stock Exchange. The sample selected using purposive method, during the 2013 until 2015. Hypothesis tested by using multiple regression analysis. In this research, firm performance were measured by Tobin's $Q$. The result of this research shows that debt ratio, firm size, return on asset and independent board have influence on firm performance. The other variables such as board size and firm age have no influence on firm performance.
\end{abstract}

Keywords: Firm Performance, Tobin's Q, Board Size, Debt Ratio, Firm Size, Firm Age, Return On Asset, Independent Board.

Abstrak: Tujuan penelitian adalah untuk memberikan bukti tentang variabel yang mempengaruhi kinerja perusahaan. Variabel-variabel ini adalah ukuran dewan, rasio utang, ukuran perusahaan, usia perusahaan, pengembalian aset, dan dewan independen. Sampel penelitian ini adalah 67 perusahaan manufaktur yang terdaftar di Bursa Efek Indonesia. Sampel dipilih menggunakan metode purposive, selama tahun 2013 hingga 2015. Hipotesis diuji dengan menggunakan analisis regresi berganda. Dalam penelitian ini, kinerja perusahaan diukur dengan Tobin's Q. Hasil penelitian ini menunjukkan bahwa rasio utang, ukuran perusahaan, pengembalian aset dan dewan independen memiliki pengaruh terhadap kinerja perusahaan. Variabel lain seperti ukuran dewan dan usia perusahaan tidak memiliki pengaruh pada kinerja perusahaan.

Kata kunci: Kinerja perusahaan, ukuran dewan, rasio utang, ukuran perusahaan, usia perusahaan, pengembalian aset, dewan independen

\section{INTRODUCTION}

The purpose of establishing a company is to maintain its survival in growth, increase profits and maintain the rate of return to be appeared constant by users of financial statements over time (Windharta \& Ahmar, 2014). According to Wira (2012), a good firm performance shows high corporate value, so that investors will be interested to invest in that company. Firm performance is one of the measure of company's capability in implementing its financial functions.

A good firm performance is preceded by investor's trust in company that their invested funds are safe and will provide a good return (Masjid \& Cahyno, 2015). Company 
performance can be used as a guide in measuring the success of a company (Fidhayatin \& Dewi, 2012). Good corporate performance can also benefit consumers, communities, and also employees. According to Sari and Usman (2014), corporate performance is a measure of the effectiveness of companies in managing assets owned to generate corporate profits. The better the performance of the company, the better the company generating the profit.

\section{Agency Theory}

In Agency Theory, the management of a company is the agent and the investors are the principal. Agents and principals have different interests. This difference often creates agency conflicts. According to Jensen and Meckling (1976), agency relationships are defined as a contract between one or more persons, in this case it is the owner and the managers who work for the owners. As a result, managers sometimes work against the wishes of the owners.

\section{Signaling Theory}

According to Gitman and Zutter (2015), signaling theory explains about how a company gives signals to the users of financial statements. These signals are information that shows management's action to realize the desire of the owner. Signals can be promotions or other information that shows the company is better than other companies.

\section{Firm Performance}

Performance is an important thing that must be achieved by every person or group within the company because the performance is a reflection of the company's ability to manage and allocate resources. According to Fidhayatin \& Dewi (2012) firm performance can be a guide in measuring the success of a company. Firm performance is a measurement of the company's achievements that arise from the management decision-making process, because it has a relationship effectiveness of capital utilization and efficiency of performance activities.

\section{Board Size and Firm Performance}

Board size is one of the main issues in corporate governance. It refers to members that attend board meetings. Some councils control the council meetings to generate different idea in order to make solutions and corporate policies to achieve goals (Karmozdi and Karmordi, 2013).

According to Sari and Usman (2014), the size of the board of commissioners positively affects the performance of the company. The size of the board of commissioners is the same as the overall management monitoring that can reduce management dominance on the board of directors and result in higher corporate performance.

$\mathrm{H}_{1}$ : There is a significant relationship between boad size and firm performance

\section{Debt Ratio and Firm Performance}

Debt to assets ratio is a measure of how much (in percentage) of the company's assets is financed from the loan of the creditor (I Cenik and Rashid, 2013). Debt ratio measures the proportion of total assets financed by corporate creditors. The higher this ratio, the greater the amount of money that can be used to increase corporate profits (Gitman and Zutter, 2015).

The results of research by Wiranata and Nugrahanti (2013) showed that debt ratio has a positive effect on company performance. When the company is underfunded to finance the company's operational activities, the company will seek loans from outside the company, because with sufficient funds, the manager is motivated to regularly utilize the funds to improve the company's performance through the profit that will usually get.

$\mathrm{H}_{2}$ : There is a significant relationship between debt ratio and firm performance. 


\section{Firm Size and Firm Performance}

Sari and Usman (2014) stated that firm size is an important concept for investors because it is an indicator of how the market perceives the company as a whole. Company size is often used as a benchmark for investors in determining investment decisions. Large companies tend to be better able to provide information about the company's internal conditions that investors need than small firms, so investors can consider investment decisions made.

According to Sari and Usman (2014) the firm size has an influence on the performance of the company so that $\mathrm{Ha}_{3}$ is accepted. The greater the number of assets a company, the larger the size of the company. This indicates that the large total assets show the company's ability to generate profits.

$\mathrm{H}_{3}$ : There is a significant relationship between firm size and firm performance

\section{Firm Age and Firm Performance}

The age of the company is a description of how long the company has been established and its ability to run the business properly. According to Meizaroh and Lucyanda (2012), the older the company, the wider its disclosure of financial information. The age of company shows the company's existence and ability to compete.

According to Lucyanda and Wardhani (2014) explains that the older the company, the longer the company operates, the higher the chances to improve the company's performance through the implementation of various corporate strategies based on a trained managerial experience.

$\mathrm{H}_{4}$ : There is a significant relationship between firm age and firm performance.

\section{Return on Asset and Firm Performance}

Return on asset is the profitability ratio that shows how big the company's ability in processing assets owned to generate profits. If the return on asset has a high value, then the company's performance in managing the asset becomes a profit. The ability of this company will be seen by investors, the better the ability of the company then the more interested investors to invest in the company (Diaz and Jufrizen, 2014).

Arsianingsih and Ardiyani (2010) stated there is positive significant of return on asset to company performance, positive result indicate that capital invested in overall assets used for company operation can generate profit for company.

$\mathrm{H}_{5}$ : There is a significant relationship between return on asset and firm performance.

\section{Independent Board and Firm Performance}

According to Putra (2015), the independent board is a member of the board of commissioners who is not affiliated with the directors, other members of the board of commissioners and the controlling shareholder, as well as free business relationships or other relationships that may affect his ability to act independently or merely for the benefit of the company.

According to Nugrahani and Nugroho (2010), the independent board has an influence on the performance of the company. This means that the increasingly independent supervisory commissioner function can reduce the directors' opportunistic behavior and management so that the firm performance becomes more effective. $\mathrm{H}_{6}$ : There is a significant relationship between independent board and firm performance

\section{RESEARCH METHOD}

The population used in this research are manufactured companies listed on the Indonesian Stock Exchange between 2013 and 2015. The sample selection techniques used in this research is the purposive sampling method. The respondents in this research are 194 companies. To test the hypotheses, a multiple regression method is used. The research model is an adaptation of the research model used by Al-Shammari and Al-Saidi (2014) with some 
modifications. The regression models uses the following equation:

\section{$\mathrm{FP}=\alpha+\beta 1 \mathrm{BS}+\beta 2 \mathrm{DET}+\beta 3 \mathrm{FSI}+\beta 4 \mathrm{FAG}+$ $\beta 5 R O A+\beta 6 B I N D+\varepsilon$}

\section{RESULTS}

Table 1

Descriptive Statistics

\begin{tabular}{|c|c|c|c|c|}
\hline Variable & Minimum & Maximum & Mean & Std. Deviation \\
\hline TOBINSQ & 0,3385 & 15,5432 & 2,004064 & 2,1710315 \\
\hline BSIZE & 2 & 11 & 4,33 & 1,930 \\
\hline DET & 0,0662 & 0,8809 & 0,402273 & 0,1778659 \\
\hline FSIZE & 11,1264 & 14,3899 & 12,304871 & 0,7068293 \\
\hline FAGE & 4 & 86 & 36,99 & 14,823 \\
\hline ROA & 0,0004 & 0,6572 & 0,89669 & 0,0841077 \\
\hline BIND & 0,0000 & 1,0000 & 0,399668 & 0,1217671 \\
\hline
\end{tabular}

Table 2

t-test result

\begin{tabular}{|l|c|c|c|}
\hline \multicolumn{1}{|c|}{ Variable } & B & T & Sig. \\
\hline (Constant) & $-6,247$ & -3.816 & 0,000 \\
\hline BS & $-0,005$ & $-0,085$ & 0,932 \\
\hline DET & 2,428 & 5,247 & 0,000 \\
\hline FSI & 0,351 & 2,372 & 0,019 \\
\hline FAG & 0,005 & 0,810 & 0,419 \\
\hline ROA & 22,007 & 20,391 & 0,000 \\
\hline BIND & 2,066 & 3,307 & 0,001 \\
\hline
\end{tabular}

\section{CONCLUSION}

The result of t-test in table 2 has shown that board size has a significant value of 0.932 where this value is greater than the alpha value of 0.05 . This means that the board size has no effect on the performance of the company due to the commissioners cannot do the coordination, communication, and decision-making in the function of control to improve the firm performance.

Debt to total asset has a significance value of 0.000 . It means that debt to total assets has an effect on the performance of the company which indicates internal funding source will not be enough to finance the overall activities of the company. The company will then search for external funding. With sufficient funds, the manager is motivated to use the funds to improve the firm performance. The firm size has a significance value of 0.019 which means firm size has an influence on the performance of the company. The greater the number of assets a company, the larger the size of the company. This indicates that the large total assets show the company's ability to generate greater profits by wisely manage the available assets and plannings so that the company will earn a great profit as well.

Firm age has a significant value of 0.419 shows the age of the company has no effect on the performance of the company. This can be due to the current high human resource development that contributes greatly to improving a firm performance. Thus, the older the company is not a guarantee that the company has a good performance.

Return on asset has a significance value of 0,000 indicating that return on asset has a positive effect on company performance. A positive return on assets shows that the capital invested in the overall assets used for the operations of the company is able to provide profits for the company. Good management of the assets owned by the company is one reflection that the company's good performance so as to survive in the future.

An independent board has a significance value of 0.001 means that an independent board has a significant on the performance of the company. This shows that the increasingly independent supervisory commissioner function can reduce the directors' opportunistic and management behaviors so that the firm performance becomes more effective and can result in performance in accordance with the company's objectives. 


\section{REFERENCES:}

Ardianingsih, Arum, dan Komala Ardiyani. 2010. Analisis Pengaruh Struktur Kepemilikan Terhadap Kinerja Perusahaan. Jurnal Pena, Vol. 19, No. 2.

Diaz, Rafika, dan Jufrizen. 2014. Pengaruh Return On Asset dan Return on Equity Terhadap Earning per Share Pada Perusahaan Asuransi yang Terdaftar di Bursa Efek Indonesia. Jurnal Manajemen \& Bisnis, Vol. 14, No. 02.

Fidhayatin, Septy Kurnia, dan Nurul Hasanah Uswati Dewi. 2012. Analisis Nilai Perusahaan, Kinerja Perusahaan Dan Kesempatan Bertumbuh Perusahaan Terhadap Return Saham Pada Perusahaan manufaktur Yang Listing Di BEl. The Indonesian accounting Revie, Vol. 2, No. 2.

Gitman, J. L, dan Chad J. Z. 2015. Principles of Managerial Finance. Pearson Education Limited 2015.

I C, Ardana. dan Rosmita Rasyid. 2013. Stock Undervaluation, Debt to Assets Ratio, Dan Cash Flow Untuk Memprediksi Stock Repurchase Pada Perusahaan Yang Tedaftar Di Bursa Efek Indonesia. Jurnal Keuangan dan Perbankan, Vol. 9, No. 2.

Jensen, C. M, and William H. Meckling. 1976. Theory of the Firm: Managerial Behavior, Agency Costs And Ownership Structure. Journal of Financial Economics 3. North-Holland Publishing Company.

Karmozdi, Mehrdad, and Hadi Karmozdi. 2013. The Effect of Board Size and Managing Director Duality on the Capital Structure of Listed Companies in Theran Stock Exchange. World Applied Sciences Journal 28. (11), 1497-1501.

Masjid, Muhammad Tabah Amirul, dan Yuli Tri Cahyono. 2015. Pengaruh Good Corporate Governance Terhadap Kinerja Perusahaan Manufaktur. Seminar Nasional dan The $2^{\text {nd }}$ Call for Syariah Paper.

Meizaroh, dan Jurica Lucyanda. 2012. Pengaruh Cororate Governance, Kinerja Perusahaan, Dan Umur Perusahan Terhadap Pengungkapan Modal Intelektual. Media Riset Akuntansi, Vol. 2, No. 1.

Putra, Firi. 2015. Peran Dan Tanggung Jawab Komisaris Independen Ditinjau Dari Undang-Undang Perseroan Terbatas. Jurnal Adminika, Vol. 1, No. 1.

Putra, I. G. Ari Pramana, dan I Wayan Ramantha. 2015. Pengaruh Profitabilitas, Umur Perusahaan, Kepemilikan Institusional, Komisaris Independen, Dan Komite Audit Pada Ketepatwaktuan Publikasi Laporan Keuangan Tahunan. E-jurnal akuntansi Universitas Udayana 10.1.

Sari, P. D, dan Bahtiar Usman. 2014. Pengaruh Board Structure dan Ownership Structure Terhadap Firm Performance Pada Perusahaan Manufaktur Yang Terdaftar Di Bursa Efek Indonesia. E- Journal Manajemen Fakultas Ekonomi Universitas Trisakti, Vol. 1, No. 2.

Sumarthanayasa, I G. E, dan I P. G. Diatmika. 2013. Analisis Return On Asset dan Forecasting Laba Pada Simpan Pinjam Lintas Desa Pada Payu Banyuning Singaraja. VOKASI Jurnal Riset Akuntansi, Vol. 2, No. 2.

Windharta, Sepriahangga Wahyu, dan Nurmala Ahmar. 2014. Pengaruh Manajemen Laba Akrual dengan Pendekatan Revenue Discretionary Model terhadap Kinerja Perusahaan. Trikonomika, Vol. 13, No.1.

Wira, Variyetni. 2012. Pengaruh Kinerja Perusahaan Terhadap Likuiditas Saham Menggunakan Trading Turnover. Jurnal Manajemen dan Kewirausahaan, Vol. 3, No. 2.

Wiranata, Yulius Ardy, dan Yeterina Widi Nugrahanti. 2013. Pengaruh Struktur Kepemilikan Terhadap Profitabilitas Perusahaan Manufaktur di Indonesia. Jurnal Akuntansi dan Keuangan, Vol. 15, No. 1. 
